\title{
Differential effect of plant lectins on mast cells of different origins
}

F.C. Lopes ${ }^{1}$, B.S. Cavada², V.P.T. Pinto ${ }^{2}$, A.H. Sampaio ${ }^{2}$ and J.C. Gomes ${ }^{1}$
${ }^{1}$ Departamento de Farmacologia, Instituto de Biociências, Universidade Estadual Paulista, Botucatu, SP, Brasil ${ }^{2}$ Departamento de Bioquímica e Biologia Molecular, Universidade Federal do Ceará, Fortaleza, CE, Brasil

\section{Correspondence}

J.C. Gomes

Departamento de Farmacologia

Instituto de Biociências, UNESP

Rubião Junior

18618-000 Botucatu, SP

Brasil

Fax: +55-14-3815-3744

E-mail: jcgomes@ibb.unesp.br

Research supported by FAPESP (No. 00/08418-4). F.C. Lopes was the recipient of a fellowship from CAPES.

Received August 4, 2003

Accepted February 3, 2005

....................

\section{Abstract}

Histamine release induced by plant lectins was studied with emphasis on the carbohydrate specificity, external calcium requirement, metal binding sites, and mast cell heterogeneity and on the importance of antibodies bound to the mast cell membrane to the lectin effect. Peritoneal mast cells were obtained by direct lavage of the rat peritoneal cavity and guinea pig intestine and hamster cheek pouch mast cells were obtained by dispersion with collagenase type IA. Histamine release was induced with concanavalin A (Con A), lectins from Canavalia brasiliensis, mannosespecific Cymbosema roseum, Maackia amurensis, Parkia platycephala, Triticum vulgaris (WGA), and demetallized Con A and C. brasiliensis, using 1-300 $\mu \mathrm{g} / \mathrm{ml}$ lectin concentrations applied to Wistar rat peritoneal mast cells, peaking on 26.9, 21.0, 29.1, 24.9, 17.2, 10.7, 19.9, and 41.5\%, respectively. This effect was inhibited in the absence of extracellular calcium. The lectins were also active on hamster cheek pouch mast cells (except demetallized Con A) and on Rowett nude rat (animal free of immunoglobulins) peritoneal mast cells (except for mannose-specific $C$. roseum, $P$. platycephala and WGA). No effect was observed in guinea pig intestine mast cells. Glucose-saturated Con A and C. brasiliensis also released histamine from Wistar rat peritoneal mast cells. These results suggest that histamine release induced by lectins is influenced by the heterogeneity of mast cells and depends on extracellular calcium. The results also suggest that this histamine release might occur by alternative mechanisms, because the usual mechanism of lectins is related to their binding properties to metals from which depend the binding to sugars, which would be their sites to bind to immunoglobulins. In the present study, we show that the histamine release by lectins was also induced by demetallized lectins and by sugar-saturated lectins (which would avoid their binding to other sugars). Additionally, the lectins also released histamine from Rowett nude mast cells that are free of immunoglobulins.

\section{Introduction}

Lectins are proteins of non-immune origin that bind to carbohydrates and sugarcontaining substances in a specific and reversible way or precipitate glycoconjugates (1). This characteristic enables lectins to in-
Key words

- Mast cells

- Histamine

- Plant lectins 
metal-binding sites are occupied $(2,3,9)$. Keller (5) first reported that Con A could induce histamine release from rat mast cells harvested from animals previously infected with the worm Nippostrongylus brasiliensis. The absence of an effect on cells from parasite-free animals, as well as temperature dependence and inhibition induced by high carbohydrate concentrations, indicate a mechanism similar to antigen-antibody reaction, possibly due to a cross-link of Fc regions of the immunoglobulin molecule. However, there is evidence that the histamine release induced by lectins can also occur through direct interaction with mast cell membrane receptors (6). A calcium requirement is another controversial point. Some papers $(7,10-12)$ have reported dependence on external calcium, whereas others $(8,13)$ have reported histamine release in the absence of calcium. Con A induces histamine release from rat, mouse, hamster, guinea pig, rabbit, and human mast cells (14), although the percentage of histamine released differs depending on the specie or tissue studied (15-18).

The objective of the present investigation was to study the histamine release induced by plant lectins (Table 1), focusing on: carbohydrate specificity, external calcium requirement, importance of metal-binding sites, mast cell heterogeneity, and the importance of antibodies bound to the mast cell membrane.

\section{Material and Methods}

\section{Animals and sensitization}

Male Wistar rats (250-280 g), hamsters (80-115 g), and Dunkin-Hartley guinea pigs (280-350 g) of both sexes were sensitized with ovalbumin ( $1 \mathrm{ml}$ of a solution containing $10 \mathrm{mg}$ plus $100 \mathrm{mg}$ aluminum hydroxide in saline) by subcutaneous (rats and hamsters) and intraperitoneal (guinea pigs) injections. The animals were used 21 to 51 days after sensitization. Six-week-old Rowett nude rats of both sexes were purchased from CEMIB-UNICAMP (Campinas, SP, Brazil). The experimental protocol used followed the ethical principles for animal research adopted by the Brazilian College of Animal Experimentation (COBEA) and was approved by the Ethics Committee for Animal Experimentation of the Institute of Bioscience, UNESP, Botucatu, SP, Brazil.

\section{Cell suspensions}

Rat peritoneal cell suspensions were obtained by lavage of the peritoneal cavity with $30 \mathrm{ml}$ Tyrode solution (137 mM NaCl, 2.7 $\mathrm{mM} \mathrm{KCl}, 1 \mathrm{mM} \mathrm{CaCl}, 0.4 \mathrm{mM} \mathrm{NaH}_{2} \mathrm{PO}_{4}$, $12 \mathrm{mM} \mathrm{NaHCO}_{3}$, and $5.6 \mathrm{mM}$ glucose), $\mathrm{pH}$ 7.4 , containing heparin (5 units $/ \mathrm{ml}$ ). The cells were recovered by centrifugation at $150 \mathrm{~g}, 22^{\circ} \mathrm{C}$, for $5 \mathrm{~min}$ and washed twice in Tyrode solution.

Hamster cheek pouch cell suspensions were obtained by dispersion with collagenase type IA as described previously (19). To prepare the guinea pig intestine cell suspensions the small intestine was removed from the animal and internally washed with Tyrode, the Peyer's patches were removed and discarded, 1-cm fragments were placed in a beaker containing $200 \mathrm{ml}$ Tyrode and constantly shaken for $20 \mathrm{~min}$ to remove the mucus. The procedure was repeated three times. Smaller fragments were cut (1-2 $\left.\mathrm{mm}^{3}\right)$ and incubated twice for $60 \mathrm{~min}$ each time with collagenase type IA using essentially the same method as for the hamster cheek pouch. The animals were killed with an overdose of ether. Cell suspensions presenting more than $15 \%$ spontaneous histamine release were discarded.

\section{Incubations}

Samples $(500 \mu 1)$ were pre-incubated in 10-ml glass tubes for $5 \mathrm{~min}$ to equilibrate the temperature $\left(37^{\circ} \mathrm{C}\right)$ before the addition of 
the compounds in a total volume never exceeding $60 \mu \mathrm{l}$. After incubation, the reactions were stopped by the addition of $1 \mathrm{ml}$ Tyrode at $4^{\circ} \mathrm{C}$ and the samples were centrifuged at $150 \mathrm{~g}, 4^{\circ} \mathrm{C}$, for $5 \mathrm{~min}$. The supernatants were poured into clean tubes, and equal volumes of Tyrode were added to the cell pellets. Perchloric acid at a final concentration of $0.4 \mathrm{M}$ was added to all tubes.

\section{Determination of histamine release}

Histamine release was determined fluorometrically (20) with an automatic modular continuous flow system (21) using a sample collector (Technicon sampler IV, Tarrytown, NY, USA), a multi-channel peristaltic pump (Technicon pump III), an extraction module, a fluorometer (Gilson model 121, Middleton, WI, USA), and a recorder (ECB model RB 201, São Paulo, SP, Brazil).

\section{Drugs, lectins and reagents}

Collagenase type IA, bovine serum albumin, compound 48/80, ionophore A23187, ovalbumin, Con A, and the lectins from Glycine max (SBA), Maackia amurensis, Triticum vulgaris (WGA), and Ulex europaeus I (UEA-I) were purchased from Sigma (St. Louis, MO, USA).

The lectin from Canavalia brasiliensis seeds was purified by affinity chromatography on a Sephadex G-50 column (22). The lectin from Parkia platycephala seeds was purified by a combination of affinity chromatography on Sephadex G-100 and mannose-agarose columns (23). Mannose-specific Cymbosema roseum and lactose-specific $C$. roseum lectins were isolated by affinity chromatography on agarose-mannose and agarose-lactose columns, respectively (Cavada BS, unpublished results). Vatairea macrocarpa lectin was isolated by affinity chromatography on a Guar gum column (24). Demetallized Con A and C. brasiliensis lectin were prepared by dialysis against $0.1 \mathrm{M}$
EDTA followed by distilled water (25). The general characteristics (26-28) of the lectins used are presented in Table 1.

\section{Statistical analysis}

Data are reported as means \pm SEM percentage of histamine released (supernatant) from the total histamine (supernatant plus pellets) present in the cells, with subtraction of spontaneous release. Data were analyzed statistically by the Student $t$-test for paired samples, with the level of significance set at $\mathrm{P}<0.05$.

\section{Results}

\section{Histamine release induced by lectins}

Con A, C. brasiliensis, mannose-specific C. roseum, $M$. amurensis, $P$. platycephala, WGA, and the demetallized lectins Con A and $C$. brasiliensis released histamine from Wistar rat peritoneal mast cells in a concentration-dependent manner. Except for Con A, these lectins also released histamine from hamster cheek pouch mast cells. Con A, $C$. brasiliensis, $M$. amurensis, and the demetallized lectins Con A and C. brasiliensis also stimulated Rowett nude rat peritoneal mast cells. Although effective in Wistar rat and hamster mast cells, mannose-specific $C$. roseum and $P$. platycephala did not stimulate Rowett nude mast cells; however, these

Table 1. General characteristics of the plant lectins studied.

\begin{tabular}{llc}
\hline Lectin source & Sugar specificity & Binding metal \\
\hline Canavalia ensiformis (Con A) & glucose/mannose & $\mathrm{Ca}^{2+}, \mathrm{Mn}^{2+}$ \\
Canavalia brasiliensis & glucose/mannose & $\mathrm{Ca}^{2+}, \mathrm{Mn}^{2+}$ \\
Parkia platycephala & glucose/mannose & - \\
Cymbosema roseum & mannose & - \\
Cymbosema roseum & lactose & - \\
Triticum vulgaris (WGA) & N-acetylglucosamine/sialic acid & - \\
Vatairea macrocarpa & galactose/N-acetylgalactosamine & - \\
Ulex europaeus I (UEA-I) & fucose & - \\
Maackia amurensis & sialic acid & $?$ \\
Glycine max (SBA) & N-acetylgalactosamine & $\mathrm{Ca}^{2+}, \mathrm{Mn}^{2+}$ \\
\hline
\end{tabular}


Table 2. Effect of temperature on the histamine release induced by demetallized Con A and Canavalia brasiliensis in Wistar rat peritoneal mast cells compared to antigen (ovalbumin) and ionophore A23187.

\begin{tabular}{ccccc}
\hline \multicolumn{4}{c}{ Histamine release (\%) } \\
\cline { 2 - 5 } & $\begin{array}{c}\text { Demetallized Con A } \\
(300 \mu \mathrm{g} / \mathrm{ml})\end{array}$ & $\begin{array}{c}\text { Demetallized C. brasiliensis } \\
(300 \mu \mathrm{g} / \mathrm{ml})\end{array}$ & $\begin{array}{c}\text { Ovalbumin } \\
(10 \mu \mathrm{g} / \mathrm{ml})\end{array}$ & $\begin{array}{c}\text { lonophore } \\
(1 \mu \mathrm{M})\end{array}$ \\
\hline $37^{\circ} \mathrm{C}$ & $24.5 \pm 3.1$ & $51.7 \pm 4.3$ & $27.8 \pm 8.7$ & $74.3 \pm 3.7$ \\
$4^{\circ} \mathrm{C}$ & $1.9 \pm 0.8^{*}$ & $5.5 \pm 2.1^{*}$ & $0.0 \pm 0.0^{*}$ & $11.2 \pm 4.8^{*}$
\end{tabular}

Data are reported as means \pm SEM for 5 experiments. Con $\mathrm{A}=$ concanavalin $\mathrm{A}$. ${ }^{*} \mathrm{P}<0.05$ compared to $37^{\circ} \mathrm{C}$ (Student $t$-test for paired samples).

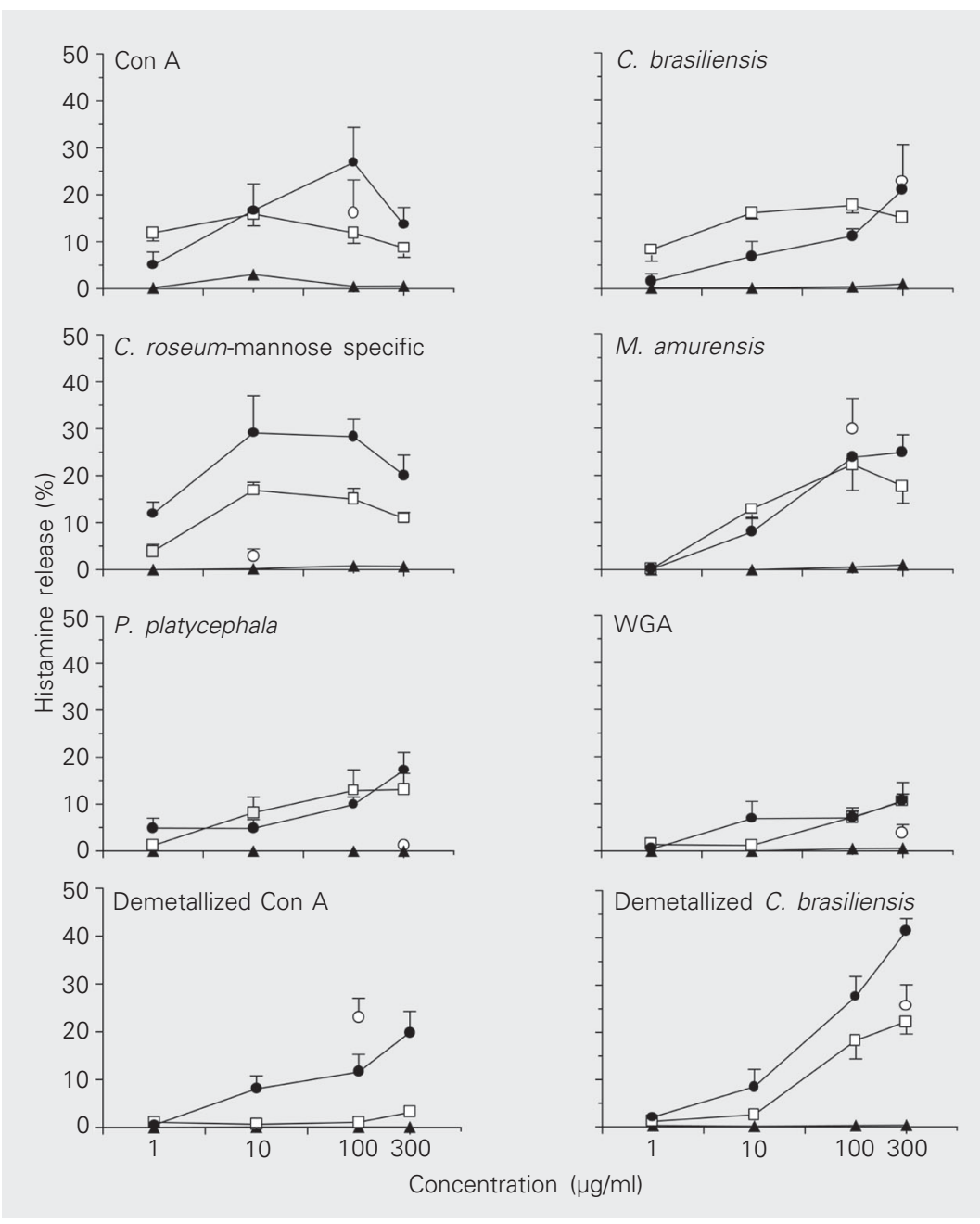

Figure 1. Lectin-induced histamine release from mast cell suspensions from Wistar rat peritoneal cavity (filled circles), hamster cheek pouch (squares), guinea pig intestine (triangles), and Rowett nude rat peritoneal cavity (open circles). The points indicate the means and the bars the respective SEM for 3-9 experiments. Some SEM were omitted to improve visualization of the figure. cells behaved like Wistar rat and hamster mast cells when stimulated with the other lectins. Wide variation in potency and efficacy was observed among the lectins studied. Regarding the lectins with activity on these three types of cell suspensions (Con A, C. brasiliensis, $M$. amurensis, and demetallized C. brasiliensis), peritoneal cells from Wistar and Rowett nude rats were found to be more responsive than hamster cheek pouch cells. All lectins studied were inactive in guinea pig intestine mast cells (Figure 1).

Lactose-specific C. roseum, SBA, UEAI and $V$. macrocarpa induced less histamine release (less than $5 \%$ ) or were inactive (data not shown).

\section{Stimulation with demetallized lectins: temperature effect}

The histamine release induced by demetallized Con $\mathrm{A}$ and $C$. brasiliensis in Wistar rat peritoneal mast cells was significantly inhibited by previous incubation at $4^{\circ} \mathrm{C}$. Histamine release induced by an antigen (ovalbumin, $10 \mu \mathrm{g} / \mathrm{ml}$ ) and ionophore A23187 (1 $\mu \mathrm{M})$ was also inhibited at this temperature (Table 2).

\section{Effect of glucose saturation}

No difference was observed in the histamine release induced by glucose-saturated and -non-saturated Con A in Wistar rat peritoneal mast cells. However, glucose saturation caused a significant inhibition of the histamine release induced by $C$. brasiliensis (Figure 2).

\section{Influence of extracellular calcium concentration}

In the absence of extracellular calcium, histamine release induced by Con A, C. brasiliensis, mannose-specific C. roseum, $M$. amurensis, $P$. platycephala, WGA, and demetallized Con A and C. brasiliensis de- 
creased significantly (Table 3 ).

\section{Discussion}

Among the lectins studied (Table 1), the glucose/mannose- or sialic acid-specific ones were active, showing that the induction of histamine release could be correlated to the specificity of the lectin binding sites. The activity of the lectins on mast cells showed different potency and efficacy depending on the animal specie and tissue. These findings indicate that these lectins are also influenced by the functional heterogeneity of mast cells, as are other secretagogues such as compound 48/80, peptide 401, dextran, ionophore A23187, as well as histamine release inhibitors like cromoglycate, quercetin, isoprenaline, and theophylline (29).

We have shown that lectins with high homology acting on the same tissue also presented variations which were considered to be probably due to the differences in the high affinity sites by which they bind to the mast cells (30). Dam et al. (31) confirmed this hypothesis, showing a significant correlation between the histamine-releasing properties of Diocleinae lectins (glucose/mannose) and their relative affinity constants for biantennary complex carbohydrate. Additionally, all of them consist of a mixture of isolectins that at different proportions could cause different effects (32).

We observed that, besides glucose/mannose-specific lectins, the lectin from $M$. amurensis and WGA also induced histamine release. M. amurensis is more specific for sialic acid and releases more histamine than WGA, which, although also binding to sialic acid, is more specific for $\mathrm{N}$-acetylglucosamine. This suggests that the activity of $M$. amurensis and WGA is related to their binding properties to sialic acid. It is possible that these lectins might activate mast cells by a mechanism similar to that of compound 48/ 80 , which has been reported to bind to sialic acid residues on the mast cell membranes
(33). A guinea pig lung cell suspension that was insensitive to compound $48 / 80$ was also insensitive to $M$. amurensis (data not shown), supporting the hypothesis of a similar mechanism.

Rowett nude rats are congenitally athymic, which means that they have greatly reduced or no immunoglobulins such as $\mathrm{IgE}$ (34). This characteristic would certainly prevent the histamine release induced by lectins through recognition of specific sugars located in the antibody molecules bound to mast cell membranes, which is the mechanism proposed for their histamine-releasing action (5,35). However, Con A, C. brasiliensis, $M$. amurensis, and demetallized Con A and $C$. brasiliensis did release a high percentage of histamine from Rowett nude rat

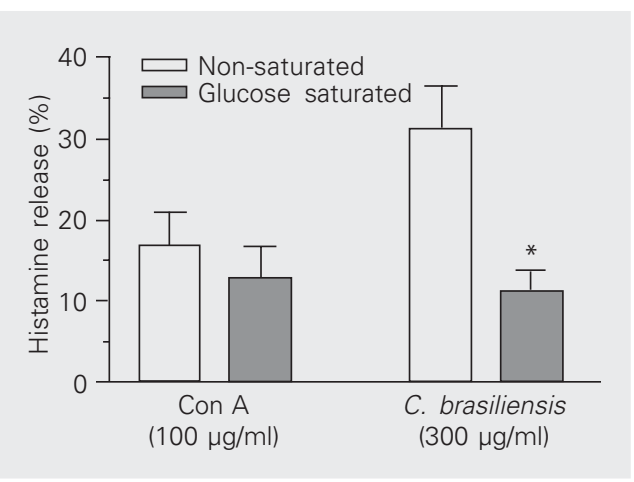

Figure 2. Histamine release induced by glucose-saturated lectins from Wistar rat peritoneal mast cells. Data are reported as means and SEM for 6 experiments. Con $\mathrm{A}=$ concanavalin $\mathrm{A}_{i}$ C. brasiliensis $=$ Canavalia brasiliensis. ${ }^{*} \mathrm{P}<0.05$ compared to non-saturated lectin (Student $t$ test for paired samples).

Table 3. Influence of extracellular calcium concentration on the histamine release induced by lectins from Wistar rat peritoneal mast cells.

\begin{tabular}{lll}
\hline & \multicolumn{2}{c}{ Histamine release $(\%)$} \\
\cline { 2 - 3 } & $0 \mathrm{mM}$ Calcium & $1 \mathrm{mM}$ Calcium \\
\hline Con A $(100 \mu \mathrm{g} / \mathrm{ml})$ & $4.7 \pm 2.0^{*}$ & $26.9 \pm 7.5$ \\
C. brasiliensis $(300 \mu \mathrm{g} / \mathrm{ml})$ & $1.3 \pm 0.5^{*}$ & $21.0 \pm 5.3$ \\
C. roseum-mannose specific $(10 \mu \mathrm{g} / \mathrm{ml})$ & $6.4 \pm 2.8^{*}$ & $29.1 \pm 7.9$ \\
M. amurensis $(100 \mu \mathrm{g} / \mathrm{ml})$ & $4.2 \pm 2.5^{*}$ & $23.8 \pm 6.4$ \\
P. platycephala $(300 \mu \mathrm{g} / \mathrm{ml})$ & $5.2 \pm 2.8^{*}$ & $17.2 \pm 3.8$ \\
WGA $(300 \mu \mathrm{g} / \mathrm{ml})$ & $1.0 \pm 0.6^{*}$ & $10.7 \pm 3.8$ \\
Demetallized Con A $(300 \mu \mathrm{g} / \mathrm{ml})$ & $3.0 \pm 1.6^{*}$ & $19.9 \pm 4.4$ \\
Demetallized C. brasiliensis $(300 \mu \mathrm{g} / \mathrm{ml})$ & $4.4 \pm 1.3^{*}$ & $41.5 \pm 2.6$
\end{tabular}

Data are reported as means \pm SEM for 4-7 experiments. Con $A=$ concanavalin $A$. ${ }^{*} \mathrm{P}<0.05$ compared to the values obtained with $1 \mathrm{mM}$ calcium (Student $t$-test for paired samples). 
peritoneal mast cells, providing strong evidence for the existence of binding sites for lectins other than sugar located on the mast cell surface antibodies. Mannose-specific $C$. roseum and $P$. platycephala, also mannose and glucose specific, although quite active in Wistar rat peritoneal and hamster cheek pouch mast cells, did not stimulate Rowett nude rat peritoneal mast cells. This fact could mean that these lectins do not have the same binding sites that would allow them to stimulate the Rowett nude mast cells as the other glucose/mannose lectins. This hypothesis does not exclude the fact that the sugarbinding properties of plant lectins are in some way related to their histamine-releasing actions.

Con A-like lectins are able to bind to carbohydrates only when the metal-binding sites are occupied first by manganese (or another divalent transition metal ion) and then by calcium. The acid treatment of these lectins reversibly removes the metal ions and destroys their ability to bind carbohydrate $(2,3,9)$. Surprisingly, demetallized Con $\mathrm{A}$ and $C$. brasiliensis can still induce histamine release by a non-cytotoxic mechanism, since the release was inhibited at $4^{\circ} \mathrm{C}$, strongly suggesting that the histamine release capacity of these lectins does not depend on the occupation of metal-binding sites and consequently that they do not need to bind to carbohydrates. It is important to note that the Tyrode used did not contain manganese or, alternatively, magnesium. Although manganese was not detected in the biological mate- rial, magnesium was found $(0.012 \mathrm{mM})$ in the concentration much lower than that necessary to occupy the binding sites of the metallized lectins $(25,36)$. Glucose saturation did not prevent the histamine-releasing activity of Con A and C. brasiliensis in Wistar rat peritoneal mast cells. However, it is important to point out that this property seems to influence the induction of histamine release since saturated $C$. brasiliensis did release less histamine than the non-saturated form. These results provide additional evidence emphasizing that these lectins can induce histamine release independent of their sugar-binding sites, and that these sites might be at least related to mast cell stimulation by lectins.

The histamine-releasing properties of lectins have been reported to depend on the extracellular calcium concentration $(7,10$ 12), a characteristic shared by the lectins used in our experiments. The histamine release induced by all lectins was also inhibited in the absence of external calcium.

Although we confirmed that some plant lectins depend on their sugar-binding properties, our results show functional evidence that the activation of mast cells by important glucose/mannose lectins such as Con A and from $C$. brasiliensis might also occur through mechanisms independent of the occupation of sugar- and metal-binding sites. Probably as a consequence, IgE bound to the mast cell membrane are not important for this type of histamine-releasing action.

\section{References}

1. Goldstein IJ, Hughes RC, Monsigny M, Osawa T \& Sharon N (1980). What should be called a lectin? Nature, 285: 66.

2. Lis H \& Sharon N (1973). The biochemistry of plant lectins (phytohemagglutinins). Annual Review of Biochemistry, 42: 541-574.

3. Sharon N \& Lis H (1990). Legume lectins - a large family of homologous proteins. FASEB Journal, 4: 3198-3208.

4. Tollefsen DM, Feagler JR \& Majerus PW (1974). Induction of the platelet release reaction by phytohemagglutinin. Journal of Clinical
Investigation, 53: 211-218.

5. Keller R (1973). Concanavalin A, a model "antigen" for the in vitro detection of cell-bound reaginic antibody in the rat. Clinical and Experimental Immunology, 13: 139-147.

6. Hook WA, Dougherty SF \& Oppenheim JJ (1974). Release of histamine from hamster mast cells by concanavalin $A$ and phytohemagglutinin. Infection and Immunity, 9: 903-908.

7. Siraganian PA \& Siraganian RP (1974). Basophil activation by con- 
canavalin A: characteristics of the reaction. Journal of Immunology, 112: $2117-2125$

8. Ennis M, Truneh A, White JR \& Pearce FL (1980). Calcium pools involved in histamine release from rat mast cells. International Archives of Allergy and Applied Immunology, 62: 467-471.

9. Sharon N (1993). Lectin-carbohydrate complexes of plants and animals: an anatomic view. Trends in Biochemical Sciences, 18: 221226.

10. Sugiyama K, Sasaki J \& Yamasaki H (1975). Potentiation by phosphatidylserine of calcium-dependent histamine release from rat mast cells induced by concanavalin A. Japanese Journal of Pharmacology, 25: 485-487.

11. Lawson D, Fewtrell C \& Raff MC (1978). Localized mast cell degranulation induced by concanavalin A-sepharose beads. Journal of Cell Biology, 79: 394-400.

12. Shores AJ \& Mongar JL (1980). Modulation of histamine secretion from concanavalin A-activated rat mast cells by phosphatidylserine, calcium, cAMP, pH and metabolic inhibitors. Agents and Actions, 10: $131-137$

13. Lansman JB \& Cochrane DE (1980). Wheat germ agglutinin stimulates exocytotic histamine secretion from rat mast cells in the absence of extracellular calcium. Biochemical Pharmacology, 29: 455-458.

14. Lagunoff D, Martin TW \& Read G (1983). Agents that release histamine from mast cells. Annual Review of Pharmacology and Toxicology, 23: 331-351.

15. Ennis M, Truneh A \& Pearce FL (1981). Lectin-induced histamine secretion from isolated rat and guinea pig mast cells. Biochemical Pharmacology, 30: 2179-2181.

16. Barrett KE \& Pearce FL (1983). A comparison of histamine secretion from isolated peritoneal mast cells of mouse and rat. International Archives of Allergy and Applied Immunology, 72: 234-238.

17. Leung KBP \& Pearce FL (1984). A comparison of histamine secretion from peritoneal mast cells of the rat and hamster. British Journal of Pharmacology, 81: 693-701.

18. Wyczolkowska J, Prouvost A \& Rydzynski K (1988). Mast cell heterogeneity and subtypes: lectin-induced histamine release from various populations of hamster mast cells. Agents and Actions, 23: 217-220.

19. Ferreira RR, Cavada BS, Moreira RA, Oliveira JTA \& Gomes JC (1996). Characteristics of the histamine release from hamster cheek pouch mast cells stimulated by lectins from Brazilian beans and concanavalin A. Inflammation Research, 45: 442-447.

20. Shore PA, Burkhalter A \& Cohn VH (1959). A method of the fluorometric assay of histamine in tissues. Journal of Pharmacology and Experimental Therapeutics, 127: 182-186.

21. Siraganian RP (1974). An automated continuous-flow system for the extraction and fluorometric analysis of histamine. Analytical Biochemistry, 57: 383-394.

22. Cavada BS, Silva LIMM, Grangeiro TB et al. (1996). Purification and biological properties of a lectin from Canavalia bonariensis Lind. seeds. In: Van Driessche E, Fisher J, Beeckmans S \& Bog-Hansen TC (Editors), Lectins, Biology, Biochemistry, Clinical Biochemistry. Textop, Hellerup, Denmark.

23. Cavada BS, Santos CF, Grangeiro TB, Silva LIMM, Campos MJO, Sousa FAM \& Calvete JJ (1997). Isolation and partial characterization of a lectin from Parkia platycephala Benth seeds. Physiology and Molecular Biology of Plants, 3: 109-115.

24. Cavada BS, Santos CF, Grangeiro TB, Nunes EP, Sales PVP, Ramos RL, Sousa FAM, Crisostomo CV \& Cavete JJ (1998). Purification and characterization of a lectin from seeds of Vatairea macrocarpa Duke. Phytochemistry, 3: 675-680.

25. Vasconcelos IM, Cavada BS, Moreira RA \& Oliveira JTA (1991). Purification and partial characterization of a lectin from the seeds of Dioclea guianensis. Journal of Food and Biochemistry, 1511: 137154.

26. Moreira RA, Ainouz IL, Oliveira JTA \& Cavada BS (1991). Plant lectins, chemical and biological aspects. Memórias do Instituto Oswaldo Cruz, 86: 211-218.

27. Sharon N \& Lis $H$ (1972). Lectins: cell-agglutinating and sugarspecific proteins. Science, 177: 949-959.

28. Rhodes JM \& Milton JD (1998). Lectin Methods and Protocols. Humana Press, Totowa, NJ, USA, 595-597.

29. Pearce FL (1986). On the heterogeneity of mast cells. Pharmacology, 32: 61-71.

30. Gomes JC, Ferreira RR, Cavada BS, Moreira RA \& Oliveira JTA (1994). Histamine release induced by glucose (mannose)-specific lectins isolated from Brazilian beans. Comparison with concanavalin A. Agents and Actions, 41: 132-135.

31. Dam TK, Cavada BS, Grangeiro TB, Santos CF, Sousa FAM, Oscarson S \& Brewer CF (1998). Diocleinae lectins are a group of proteins with conserved binding sites for the core trimannoside of asparagine-linked oligosaccharides and differential specificities for complex carbohydrates. Journal of Biological Chemistry, 273: 12082-12088

32. Cavada BS, Barbosa T, Arruda S, Grangeiro TB \& Barral-Netto M (2001). Revisiting proteus: Do minor changes in lectin structure matter in biological activity? Lessons from and potential biotechnological uses of the Diocleinae subtribe lectins. Current Protein and Peptide Science, 2: 123-135.

33. Mousli M, Bronner C, Bueb JL, Tschirhart E, Gies JP \& Landry Y (1989). Activation of rat peritoneal mast cells by substance $P$ and mastoparan. Journal of Pharmacology and Experimental Therapeutics, 250: 329-335.

34. Diel F \& Usadel KH (1984). Somatostatin-induced histamine release in mast cell incubates from thymus aplastic nude rats. Agents and Actions, 14: 506-509.

35. Magro AM \& Bennich H (1977). Concanavalin A induced histamine release from human basophils in vitro. Immunology, 33: 51-58.

36. Moreira RA, Barros ACH, Steward JC \& Pusztai A (1983). Isolation and characterization of a lectin from the seeds of Dioclea grandiflora Mart. Planta, 158: 63-69. 